\title{
The Influence of Slope Morphology upon the Thermic Regime of Soil andManagement Practices in the Transylvanian Plain
}

\author{
Paula Ioana MORARU ${ }^{1 *}$, Teodor RUSU ${ }^{1}$, Ileana BOGDAN ${ }^{1}$, Adrian POP ${ }^{1}$, Camelia COSTE ${ }^{1}$, Bogdan \\ DUDA $^{1}$, Tudor SĂLĂGEAN ${ }^{1}$, Mara ŞOPTEREAN ${ }^{1}$, Ilarie IVAN ${ }^{2}$
}

${ }^{1)}$ Faculty of Agriculture, University of Agricultural Sciences and Veterinary Medicine Cluj-Napoca, 3-5, Manastur Street, 400372, Romania;

2)Technical University of Cluj, B-dul Muncii, 103-105, 400641, Cluj-Napoca, Romania;

*corresponding author: moraru_paulaioana@yahoo.com

Bulletin USAMV series Agriculture 71(2)/2014

Print ISSN 1843-5246; Electronic ISSN 1843-5386

DOI 10.15835/buasvmcn-agr: 10292

\begin{abstract}
The aim of this paper is to establish the influence of the relief elements of versants in the Transylvania Plain and of climatic factors on the thermal regime of these soils and on the agricultural management measures. Through its components - precipitation, wind, temperature - the climate represents the most active external dynamic agent, causing the emergence and development of the land degradation process in this area. In order to determine the influence of the climatic factor on the agro-technical characterization of land according to slope morphology, 11 HOBO Micro Stations have been implemented from April to October 2011 in the locality Căianu, with various altitude at exposure coverage. By analyzing the data recorded during April-October 2011, we obtain a similar situation of the southern slopes as compared with the south-eastern and eastern versants - $43.8 \mathrm{~mm}$ less rainfall, higher temperatures by $0.37^{\circ} \mathrm{C}$ in the air, by $1.91^{\circ} \mathrm{C}$ at $10 \mathrm{~cm}$, by $2.22^{\circ} \mathrm{C}$ at $20 \mathrm{~cm}$, and by $2.43^{\circ} \mathrm{C}$ at $30 \mathrm{~cm}$ soil depth compared to northern and north-western slopes. These issues, supplemented by those connected to slope, require special agro-technical measures generated by the Transylvanian Plain topography.
\end{abstract}

Keywords: slope morphology, crop structure, soil temperature.

\section{INTRODUCTION}

Climatic, biotic and edaphic factors, which determine plant growth and the size and quality of the crop manifest very differently over the various agricultural areas. The relief, the climatic characteristics of agricultural areas and soil require zoning of crops, varieties and hybrids, followed by the adjustment of technology in order to reduce to a minimum the limiting actions of regional factors (deficient or excessive moisture, low content of humus and nutrients etc.). The various landforms - by sweep, dimensions, complexity etc. - significantly affect the constituted soils, creating specific topoclimates and differentiates the elements of technology (Hoble et al., 2010). The landforms constituted by geological erosion: slopes, meadows, terraced hillsides, peaks, pla- teaus, present important pedological, technical and microclimatic variations, which must be revealed in order to be able to recommend specific agro-technical measures. These differentiations have to be taken into account during the process of drawing up the differentiated system of agriculture. In other words, the technology applied should be differentiated according to the concrete conditions of each parcel (Rusu et al., 2013).

From a geomorphologic point of view, in the Transylvanian Plain,one can encounter the following items: moderately dip slopes, scarp slopes with constituted basal glacis, inter fluvial peaks and riverine meadows of small streams. Gentle to moderate dipslopes represent elements of a dome and brachi anticline relief and characterized through northern and north-western exposure, re- 
latively uniform, with a length value above $1.5 \mathrm{~km}$ and with a slope of $10-20 \%$. Along the mountain slope, the value of the slopemodifies, thus reaching the demarcation of aninferior sector, where the slope is characterizedby a dip of $5-10 \%$, a middle section with a dip of $10-15 \%$ and the upper sector with a dip value of $15-25 \%$ (sector which makes the connection with the interfluvial peaks) (Pop, 2001).

The slopes with a steep dip are generally short $(0.5-1.0 \mathrm{~km})$, with a southern and south western exhibition with a dip which sometimes even exceeds the value of $60 \%$, being at the same time strongly affected by erosion processes. At the superior part of these slopes,a series of carved cornices emerge from place to place, whichhave at the basis important amounts of material resulting from landslide and slump. Eroded material is accumulated in the delayed sectors of the slope, giving birth to landforms of the monticular type (or costreams).

Interfluvial peaks are situated in the upper part of slopes, being highly distinguished within the relief in particular due to their large aspect, with a gentle dip and different directions. The interfluvial peaks of this territory are relatively narrow, asymmetrical, bordered by south and south western steeped dip slopes and by an extensive monocline to the north and northeast (Baciu, 2006). The fluviatil meadows are covered in a general feature, namely a width of approximately 100-200 meters in major beds and $80-150 \mathrm{~m}$ in minor beds. These landforms are distinguished throughtheir very wide aspect, as a reminiscence of intensive fluvial activities during the quaternary epoch (Holocene), with groundwater close to the surface, to which a pedologic wrapper dominated by hydro-morphic soils are added. Due to the influence of the gleization processes which affect the soils on these landforms, land use is directedtowards meadows and pastures (Macet et al., 1987).

During the process of formation, evolution and individualization of technological characteristics of soils, a multitude of natural, social and economic factors partake, either directly or indirectly (Bunescu, 2005). Natural factors refer to climatic factors, of relief, soil and parent rock, vegetation, and the social-economic ones relegate to human activity. It should be noted that the manoeuvre of natural factors, during the onset and maintenance of soil related processes are more or less exercised in relation to the work carried out by humans (Weindorf et al., 2011). Parent rock and soil formed on it may contribute to the definition of the technological properties of the land in that area in the following case:the parent rock is tough (conglomerates, sandstone, etc); in these situations the constituted soil is thin, retains a small amount of rainwater and can be easily trained and washed down the valley, because the hard rock does not allow the absorption of larger amounts of water, and within a relatively short period, hard rock resurfaces (Naum, 1974);

The soil layer formed on brittle rocksis deeper, mellow, porous, the water thus infiltrating more easily and fostering the development of a naturalvegetation well completed (Pop, 2001). The phenomenon of erosion, both the superficial and the deep one, is accompanied in the Transylvanian Plain by the transfer of dislocated materials and their sedimentation in the lower parts, resulting in the phenomena of colluviation and alluviation. The association of these phenomena of land degradationleads to various types of degradation in the Transylvanian Plain territory, of which the most common are the following: calloused pastures, with erosion in small patches among the grazing paths, forming the so-called "skinned ribs"; agricultural land, with the erosion of the surface with gullies and gaps; pastures and hayfields poorly completed, with deep erosions.

The aim of this paper is to establish the influence of the relief elements of versants in the Transylvanian Plain and of climatic factors on the thermal regime of these soils and on the agricultural management measures. Through its components (precipitation, wind, temperature), the climate represents the most active external dynamic agent, causing the emergence and development of the land degradation process in this area.

\section{MATERIALS AND METHODS}

In order to determine the influence of climatic factor on the agro-technical characterization of land according to slope morphology, 11 HOBO Micro Stations (H21-002, On-set Computer Corp., Bourne, MA, USA) have been implemented from April to October 2011 in the locality Căianu, with various altitudes and exposure coverage:

Station 1: altitude $311 \mathrm{~m}$, SE exposure, rain gauge. 
Station 2: altitude $440 \mathrm{~m}, \mathrm{~N}$ exposure.

Station 3 altitude $360 \mathrm{~m}, \mathrm{~N}$ exposure, rain gauge.

Station 4: altitude $441 \mathrm{~m}$, NW exposure.

Station 5: altitude $420 \mathrm{~m}$, NE exposure, rain gauge.

Station 6: altitude $341 \mathrm{~m}$, E exposure.

Station 7: altitude $369 \mathrm{~m}, \mathrm{~S}$ exposure.

Station 8: altitude $380 \mathrm{~m}, \mathrm{~W}$ exposure.

Station 9: altitude $387 \mathrm{~m}, \mathrm{~W}$ exposure, summit of the hill.

Station 10: altitude $330 \mathrm{~m}, \mathrm{~W}$ exposure.

Station 11: altitude 398 m, S exposure, rain gauge.

HOBOSmartTemp(S-TMB-M002) temperature sensors and Decagon EC-5 (S-SMC-M005) moisture sensors were connected to HOBO Micro Stations. Additionally, at 4 of the 11 sites, tipping bucket rain gauges (RG3-M) were deployed to measure precipitation (On-set Computer Corp., Bourne, MA, USA). Each station stored electronic data regarding ground temperature at 3 depths $(10,20,30 \mathrm{~cm})$, humidity at a depth of $10 \mathrm{~cm}$, air temperature $(1 \mathrm{~m})$ and precipitation. Data were downloaded from the Micro Stations via a laptop computer using HOBO ware Pro Software Version 2.3.0 (On-set Computer Corp., Bourne, MA, USA).

\section{RESULTS AND DISCUSSIONS}

Soil temperature is influenced by the positioning of the station on the versant. At $10 \mathrm{~cm}$ depth (Tab. 1), during the research period, the lowest temperature was recorded on the northern slope $\left(15.45^{\circ} \mathrm{C}\right)$ followed by the western versant $\left(15.72^{\circ} \mathrm{C}\right)$, whereas the highest temperature was registered on the eastern $\left(17.66^{\circ} \mathrm{C}\right)$, north-eastern $\left(17.59^{\circ} \mathrm{C}\right)$ and southern versants $\left(17.28^{\circ} \mathrm{C}\right)$. If the temperature recorded is in direct relationship with the slope exposure, moisture (Tab. 2) registers a much higher oscillation even on the same slope, being influenced by the dip slope, thus we have an average humidity of $0.23 \mathrm{~m}^{3} / \mathrm{m}^{3}$ at station 2 and $0.17 \mathrm{~m}^{3} / \mathrm{m}^{3}$ at the station 3 . Temperature recorded at $20 \mathrm{~cm}$ depth (Tab. 3) and $30 \mathrm{~cm}$ (Tab. 4) follows the same trend registered at $10 \mathrm{~cm}$ (Fig. 1), showing lower temperatures for the northern and western versants, respectively temperatures by $2^{\circ} \mathrm{C}$ higher at southern and eastern versants.

The air temperature was recorded at stations equipped with rain gauge. The lowest temperature was of $16.58^{\circ} \mathrm{C}$ at the station with south-eastern exhibition, followed by an average temperature of $16.61^{\circ} \mathrm{C}$ recorded at the station with the northern exhibition. At station 5: $16.91^{\circ} \mathrm{C}$ were recorded, with a north-eastern exposure, and an average temperature of $16.98^{\circ} \mathrm{C}$ was registered at station 11 with southern exhibition (Tab. 5).

The rainfall values recorded from April to October, situated between 262.2-306 mm, the lowest value being registered at station 11 , with the southern exposure, and the highest at station 5 , with north-eastern exhibition. Intermediate values of 297.6 and $300.8 \mathrm{~mm}$ were recorded at stations 3 and 1, with northern, respectively south-eastern exposure (Tab. 6). Differences in precipitation are found in soil humidity and temperature, southern,south-eastern and eastern versants being warmer and more droughty with $0.37^{\circ} \mathrm{C}$ in air, with $1.91-2.43^{\circ} \mathrm{C}$ in soil, and the northern, north-western and western slopes being cooler and more humid.

Tab. 1. Average temperatures $\left({ }^{\circ} \mathrm{C}\right)$ at the depth of $10 \mathrm{~cm}$ in soil recorded from April to October, 2011 , at Căianu

\begin{tabular}{lccccccccccc}
\hline \multirow{2}{*}{ Month } & Station & $\begin{array}{c}\text { Station } \\
1 / \mathrm{SE}\end{array}$ & $\begin{array}{c}\text { Station } \\
2 / \mathrm{N}\end{array}$ & $\begin{array}{c}\text { Station } \\
\text { A }\end{array}$ & $\begin{array}{c}\text { Station } \\
4 / \mathrm{NV}\end{array}$ & $\begin{array}{c}\text { Station } \\
5 / \mathrm{NE}\end{array}$ & $\begin{array}{c}\text { Station } \\
6 / \mathrm{E}\end{array}$ & $\begin{array}{c}\text { Station } \\
7 / \mathrm{S}\end{array}$ & $\begin{array}{c}\text { Station } \\
8 / \mathrm{V}\end{array}$ & $\begin{array}{c}\text { Station } \\
10 / \mathrm{V}\end{array}$ & $\begin{array}{c}\text { Station } \\
11 / \mathrm{S}\end{array}$ \\
\hline April & 10.05 & 9.48 & 9.41 & 9.51 & 11.26 & 11.36 & 11.34 & 9.55 & 11.35 & 10.64 & 11.75 \\
\hline May & 15.13 & 13.55 & 14.70 & 14.80 & 16.81 & 16.91 & 16.06 & 15.04 & 16.42 & 14.92 & 15.93 \\
\hline June & 20.64 & 18.12 & 19.40 & 19.30 & 21.25 & 21.15 & 19.88 & 19.77 & 19.97 & 18.74 & 19.48 \\
\hline July & 21.02 & 19.11 & 21.36 & 21.26 & 22.10 & 22.00 & 21.38 & 21.69 & 21.28 & 19.66 & 20.85 \\
\hline August & 19.70 & 20.13 & 20.50 & 20.60 & 21.49 & 21.79 & 21.67 & 21.06 & 21.04 & 18.68 & 21.95 \\
\hline September & 16.77 & 16.44 & 17.53 & 17.63 & 19.02 & 19.12 & 19.48 & 18.15 & 16.70 & 16.70 & 18.65 \\
\hline October & 9.20 & 11.37 & 10.23 & 10.33 & 11.19 & 11.29 & 12.70 & 11.19 & 10.70 & 10.70 & 12.36 \\
\hline Average & $\mathbf{1 6 . 0 7}$ & $\mathbf{1 5 . 4 5}$ & $\mathbf{1 6 . 1 6}$ & $\mathbf{1 6 . 2 0}$ & $\mathbf{1 7 . 5 9}$ & $\mathbf{1 7 . 6 6}$ & $\mathbf{1 7 . 5 0}$ & $\mathbf{1 6 . 6 4}$ & $\mathbf{1 6 . 7 8}$ & $\mathbf{1 5 . 7 2}$ & $\mathbf{1 7 . 2 8}$ \\
\hline
\end{tabular}


Tab. 2. Soil humidity $\left(\mathrm{m}^{3} / \mathrm{m}^{3}\right)$ at the depth of $10 \mathrm{~cm}$ in soil recorded from April to October, 2011, at Căianu

\begin{tabular}{lccccccccccc}
\hline \multirow{2}{*}{ Month } & $\begin{array}{c}\text { Station } \\
1 / \mathrm{SE}\end{array}$ & $\begin{array}{c}\text { Station } \\
2 / \mathrm{N}\end{array}$ & $\begin{array}{c}\text { Station } \\
\text { 3 / N }\end{array}$ & $\begin{array}{c}\text { Station } \\
4 / \mathrm{NV}\end{array}$ & $\begin{array}{c}\text { Station } \\
5 / \mathrm{NE}\end{array}$ & $\begin{array}{c}\text { Station } \\
6 / \mathrm{E}\end{array}$ & $\begin{array}{c}\text { Station } \\
7 / \mathrm{S}\end{array}$ & $\begin{array}{c}\text { Station } \\
8 / \mathrm{V}\end{array}$ & $\begin{array}{c}\text { Station } \\
9 / \mathrm{V}\end{array}$ & $\begin{array}{c}\text { Station } \\
10 / \mathrm{V}\end{array}$ & $\begin{array}{c}\text { Station } \\
11 / \mathrm{S}\end{array}$ \\
\hline April & 0.32 & 0.29 & 0.35 & 0.34 & 0.32 & 0.35 & 0.37 & 0.31 & 0.36 & 0.29 & 0.35 \\
\hline May & 0.23 & 0.25 & 0.18 & 0.19 & 0.31 & 0.33 & 0.32 & 0.21 & 0.31 & 0.22 & 0.33 \\
\hline June & 0.21 & 0.23 & 0.08 & 0.09 & 0.28 & 0.29 & 0.28 & 0.07 & 0.27 & 0.16 & 0.27 \\
\hline July & 0.27 & 0.28 & 0.18 & 0.19 & 0.33 & 0.34 & 0.32 & 0.22 & 0.33 & 0.23 & 0.29 \\
\hline August & 0.26 & 0.25 & 0.14 & 0.13 & 0.32 & 0.34 & 0.27 & 0.21 & 0.27 & 0.15 & 0.29 \\
\hline September & 0.21 & 0.19 & 0.04 & 0.05 & 0.31 & 0.30 & 0.22 & 0.12 & 0.08 & 0.08 & 0.24 \\
\hline October & 0.19 & 0.15 & 0.05 & 0.01 & 0.21 & 0.25 & 0.18 & 0.10 & 0.05 & 0.05 & 0.19 \\
\hline Average & 0.24 & 0.23 & 0.17 & 0.15 & 0.29 & 0.31 & 0.28 & 0.18 & 0.24 & 0.17 & 0.28 \\
\hline
\end{tabular}

Tab. 3. Average temperatures $\left({ }^{\circ} \mathrm{C}\right)$ at the depth of $20 \mathrm{~cm}$ in soil recorded from April to October, 2011 , at Căianu

\begin{tabular}{lccccccccccc}
\hline Month & $\begin{array}{c}\text { Station } \\
\text { 1/SE }\end{array}$ & $\begin{array}{c}\text { Station } \\
\text { 2/N }\end{array}$ & $\begin{array}{c}\text { Station } \\
\text { 3/N }\end{array}$ & $\begin{array}{c}\text { Station } \\
4 / \mathrm{NV}\end{array}$ & $\begin{array}{c}\text { Station } \\
5 / \mathrm{NE}\end{array}$ & $\begin{array}{c}\text { Station } \\
6 / \mathrm{E}\end{array}$ & $\begin{array}{c}\text { Station } \\
7 / \mathrm{S}\end{array}$ & $\begin{array}{c}\text { Station } \\
8 / \mathrm{V}\end{array}$ & $\begin{array}{c}\text { Station } \\
9 / \mathrm{V}\end{array}$ & $\begin{array}{c}\text { Station } \\
10 / \mathrm{V}\end{array}$ & $\begin{array}{c}\text { Station } \\
11 / \mathrm{S}\end{array}$ \\
\hline April & 8.53 & 8.67 & 8.80 & 8.90 & 10.83 & 10.93 & 10.83 & 9.32 & 10.90 & 10.11 & 10.16 \\
\hline May & 13.35 & 12.93 & 13.70 & 13.80 & 16.20 & 16.30 & 15.14 & 14.55 & 15.65 & 14.28 & 15.73 \\
\hline June & 17.76 & 18.00 & 18.19 & 18.29 & 20.62 & 20.72 & 19.02 & 19.25 & 20.25 & 18.24 & 20.67 \\
\hline July & 19.49 & 19.38 & 20.20 & 20.30 & 21.70 & 21.60 & 20.60 & 21.15 & 21.24 & 19.36 & 22.55 \\
\hline August & 19.64 & 18.91 & 20.00 & 20.01 & 21.64 & 21.54 & 21.02 & 20.73 & 20.18 & 18.59 & 21.99 \\
\hline September & 17.53 & 16.88 & 17.45 & 17.55 & 19.23 & 19.13 & 19.22 & 18.11 & 16.70 & 16.70 & 18.86 \\
\hline October & 11.63 & 11.09 & 11.10 & 11.20 & 11.45 & 11.55 & 13.25 & 11.64 & 11.22 & 11.22 & 11.48 \\
\hline Average & 15.42 & 15.12 & 15.63 & 15.72 & 17.38 & 17.40 & 17.01 & 16.39 & 16.59 & 15.50 & 17.34 \\
\hline
\end{tabular}

Tab. 4. Average temperatures $\left({ }^{\circ} \mathrm{C}\right)$ at the depth of $30 \mathrm{~cm}$ in soil recorded from April to October, 2011 , at Căianu

\begin{tabular}{lccccccccccc}
\hline \multirow{2}{*}{ Month } & $\begin{array}{c}\text { Station } \\
1 / \mathrm{SE}\end{array}$ & $\begin{array}{c}\text { Station } \\
2 / \mathrm{N}\end{array}$ & $\begin{array}{c}\text { Station } \\
3 / \mathrm{N}\end{array}$ & $\begin{array}{c}\text { Station } \\
4 / \mathrm{NV}\end{array}$ & $\begin{array}{c}\text { Station } \\
5 / \mathrm{NE}\end{array}$ & $\begin{array}{c}\text { Station } \\
6 / \mathrm{E}\end{array}$ & $\begin{array}{c}\text { Station } \\
7 / \mathrm{S}\end{array}$ & $\begin{array}{c}\text { Station } \\
8 / \mathrm{V}\end{array}$ & $\begin{array}{c}\text { Station } \\
9 / \mathrm{V}\end{array}$ & $\begin{array}{c}\text { Station } \\
10 / \mathrm{V}\end{array}$ & $\begin{array}{c}\text { Station } \\
11 / \mathrm{S}\end{array}$ \\
\hline April & 8.48 & 8.25 & 8.86 & 8.96 & 10.28 & 10.38 & 10.41 & 9.05 & 9.51 & 9.67 & 11.78 \\
\hline May & 13.01 & 12.37 & 13.68 & 13.78 & 15.66 & 15.76 & 14.33 & 13.92 & 14.69 & 13.75 & 17.29 \\
\hline June & 17.46 & 17.05 & 17.07 & 17.17 & 19.81 & 19.91 & 18.21 & 18.61 & 19.59 & 17.75 & 20.94 \\
\hline July & 19.53 & 18.98 & 19.18 & 19.08 & 20.89 & 20.99 & 19.85 & 20.57 & 21.10 & 19.00 & 21.89 \\
\hline August & 19.55 & 19.23 & 19.28 & 19.38 & 21.43 & 21.53 & 20.40 & 20.39 & 21.27 & 18.42 & 20.80 \\
\hline September & 17.52 & 17.18 & 20.61 & 20.91 & 19.13 & 19.23 & 19.01 & 18.14 & 18.53 & 16.66 & 18.68 \\
\hline October & 12.03 & 12.06 & 12.26 & 12.36 & 12.26 & 12.36 & 13.99 & 12.24 & 11.97 & 11.66 & 10.75 \\
\hline Average & $\mathbf{1 5 . 3 7}$ & $\mathbf{1 5 . 0 1}$ & $\mathbf{1 5 . 8 5}$ & $\mathbf{1 5 . 9 4}$ & $\mathbf{1 7 . 0 6}$ & $\mathbf{1 7 . 1 6}$ & $\mathbf{1 6 . 6 0}$ & 16.13 & 16.67 & 15.27 & 17.44 \\
\hline
\end{tabular}




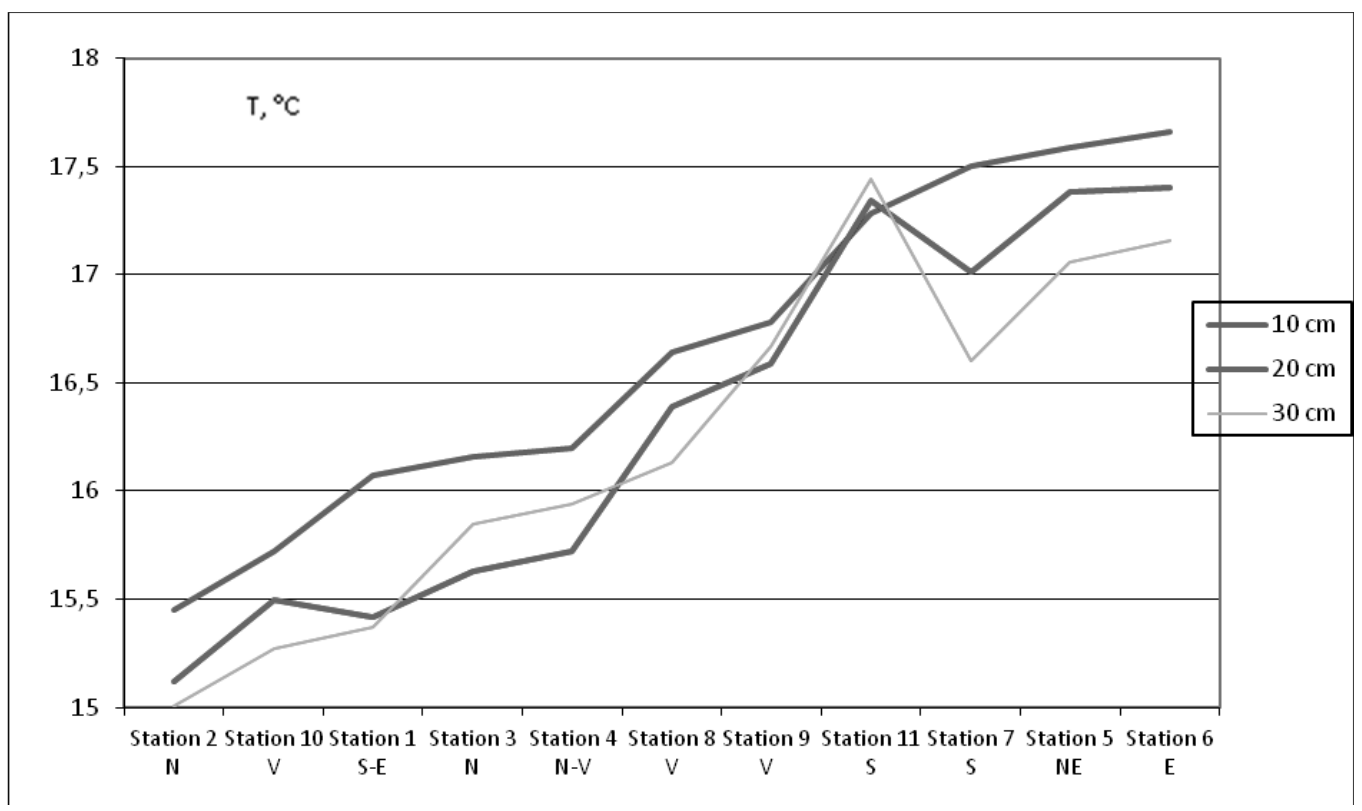

Fig. 1. Average temperatures recorded from April to October, 2011, at Căianu, at the depth of 10,20 and $30 \mathrm{~cm}$ in soil $\left({ }^{\circ} \mathrm{C}\right)$

Tab. 5. Average air temperatures $\left({ }^{\circ} \mathrm{C}\right)$ recorded from April to October 2011, at Căianu

\begin{tabular}{lcccc}
\hline \multirow{2}{*}{ Month } & Station & Station & Station & Station \\
& $1(\mathrm{SE})$ & $3(\mathrm{~N})$ & $5(\mathrm{NE})$ & $11(\mathrm{~S})$ \\
\hline April & 11.13 & 10.74 & 10.91 & 11.69 \\
\hline May & 16.05 & 16.12 & 16.09 & 16.32 \\
\hline June & 20.44 & 20.33 & 20.44 & 20.09 \\
\hline July & 21.35 & 20.98 & 21.36 & 20.9 \\
\hline August & 21.28 & 21.19 & 21.49 & 21.42 \\
\hline September & 17.99 & 18.66 & 18.9 & 18.76 \\
\hline October & 7.82 & 8.26 & 9.21 & 9.71 \\
\hline Average & 16.58 & 16.61 & 16.91 & 16.98 \\
\hline
\end{tabular}

Tab. 6. Precipitations recorded from April to October, 2011, at Căianu

\begin{tabular}{lcccc}
\hline Month & Station & Station & Station & Station \\
& $1(\mathrm{SE})$ & $3(\mathrm{~N})$ & $5(\mathrm{NE})$ & $11(\mathrm{~S})$ \\
\hline April & 29.8 & 35.8 & 31.6 & 26.6 \\
\hline May & 29 & 48.4 & 43.2 & 37 \\
\hline June & 59 & 56 & 54.2 & 42.6 \\
\hline July & 139.6 & 123.2 & 131.4 & 112.8 \\
\hline August & 24.4 & 21.6 & 24.4 & 23 \\
\hline September & 9 & 2 & 11 & 9 \\
\hline October & 10 & 10.6 & 10.2 & 11.2 \\
\hline Average & 300.8 & 297.6 & 306 & 262.2 \\
\hline
\end{tabular}


By analyzing the data recorded during AprilOctober 2011, we obtain a similar situation of the southern slopes as compared with the southeastern and eastern versants - $43.8 \mathrm{~mm}$ less rainfall, higher temperatures by $0.37^{\circ} \mathrm{C}$ in the air and by $1.91^{\circ} \mathrm{C}$ at $10 \mathrm{~cm}$, by $2.22^{\circ} \mathrm{C}$ at $20 \mathrm{~cm}$, by $2.43^{\circ} \mathrm{C}$ at $30 \mathrm{~cm}$ soil depth compared to northern, north-western slopes. These issues, supplemented by those connected to slope, require special agrotechnical measures generated by the Transylvanian Plain topography.

Characterization and analysis of the phenomena of soil improvement in this area aim at supplementing the existing research with new elements, important from the agricultural and ecological point of view, as well as presenting the severity and spatial dispersion of the phenomena, in order to establish the criteria for improved usageand erosion cessation through specific anti-erosive agricultural technologies. Among the categories of slope processes, surface erosionreacts mostly, being present by stabilised landslides and active and semi-active landfalls.

Land topography, along with vegetation or alone, holds the key to the development of surface leakage, having a decisive influence on the process of hydric erosion (Selby, 1993). Grass or woody vegetation is the most important factor for soil protection and conservation on the dip lands of the Transylvanian plain. The role of vegetation, with the presence of vegetable debris, is closely tied to its way and degree of coverage, with an overwhelming influence on soil protection, through its direct and indirect effects depending on the composition, density and duration of protection. The direct effects include: the annihilation of the workforce impact of raindrops hitting the ground during the fall, avoidance of crust formation, ensuring water infiltration in greater quantity through the crust, reducing the amount of water drained from soil surface. Indirect effects of vegetation are: increase insoil porosity, providing constant temperature in summer and winter, increased cohesion, ensured bythe root system.

The increase of arable surfaces on sloping lands as a result of deforestation and fallowing, combined with the implementation of inadequate agro-techniques, leads to negative consequences on the ground coating (Montgomery, 2007). The structure of cultures on hillsides, the varieties of cultivated plants and tillage systems contribute to the emergence and amplification of the morphogenetic processes. Micro-relief forms resulted through deep erosion (the streaming, the draining, the gully, the gap, the torrent) generate important technological differentiations for agricultural production.

The "user mode" of lands, although it had some stability in terms of its overall structure, has however suffered from frequent alterations, year after year,as far as the quantitative weighting of the various usages is concerned. The outcome of these modifications was at first the growth of cultivated areas and the decrease, as a result of deforestation and fallowing, of the areas taken up by hayfields and forests. Deforestation, being accompanied by the lack of applyinganti-erosive measures, hasengendered important changes in natural balances (Rusu, 2011). The relationship between infiltration and evaporation, between infiltration and precipitation have changed, whereas the relationship between cohesion and resistance to erosion has also modified, etc.,elements which have favoured the emergence or intensification of various morphological processes on versants.

The structure of cultures has contributed to the emergence and amplification of the morphogenetic processes, both by poor coagulation some of them have, as well as through agro-technical maintenance works, which weaken the cohesion of the soil particles. Corn, beets, potatoes, and other hoeing plant surfaces, being cultivatedon important surfaces and even on steep dip slopes, have given rise to favorable conditions for carrying out the processes of erosion. In such cases, soil, largely denuded, mellow and with a weak cohesion, has been easily subject to erosion by disintegration of particles and deployment of the fine, nonaggregated material. In time, the arable layer has been increasingly moretrusted aside, linear erosion formations have emergedand, eventually, the land has become quite counterproductive on some surfaces (Dîrja, 2000). As a consequence, the removal of substantial amounts of fertile topsoil takes place and its depositing on flat surfaces or with a low dip at the base of the slope. The phenomenon, although it can be quite commonly found in the territory studied, distinguishes especially on slopes with a dip above $8^{\circ}$ where erosion processes have reached a very advanced stage. 
Agro-technical methods used in the cultivation of land have been, in many cases, contributory factors, if not provoking, of some degradation processes (Lal, 2001). Plowing, harrowing, certain tillage systems of sowing and culture maintenance, carried out perpendicularlyon level curves, give birth on the direction of the slope dipto a multitude of small grooves. During downpour, when on soil surface a relatively large volume of wateris falling, these groovescarry away the water and steer it along the slopes and, as a result of erosion that occurs, they are transformed into a dense network of gullies. During the followingdownpour the erosion continues, and, depending on the type of soil, of the degree of vegetation coverage and the value of the slope, the gullies are transformed into ravines or even pot holes (Dîrja, 2000).

\section{CONCLUSION}

Land degradation in the Transylvanian Plain and its effects should be analysed through the prism of the local physical and geographical conditions. These conditions create anauspicious frameworkfor the deployment of morphogenetic processes actuated by human activity, as well as for the ones triggered by natural mechanisms, intensifying the pace and their territorial expansion. Accordingly,precipitations are firstly noticed, which, although in terms of annual sums do not raise special problems, through their regimethey become highly influential. This situation occurs during March to November when the soil, through agro-technical work is always mellow, the amount of rainfall streaming on slopes is relatively high $(40-50 \%$ of the total rainfall), and torrential rains have increased aggressiveness due to the high intensity and occurrence of the downpour nucleus after the ground has been soaked with water. Along with precipitation other elements are involved: relief, by the accentuated degree of fragmentation and through the tilting of the slopes; vegetation, through the predominance of cultivated plants and through the advanced stage of degradation of plant associations on meadows (especially on the southern exposed slopes); lythology, through the predominance of loose rocks (sand, marl, sandstone etc.).

The station's positioning on the versant directly influences soil temperature, on the northern slope the lowest temperature being registered, and on the eastern and north-eastern, the largest. The situation is changed when soil moisture values are being analysed, sinceone cannot see a direct relationship between slope exhibition and humidity. Important oscillations were recorded even in the case of the same slope, the humidity value being influenced by the land dip.

By analyzing the data recorded during AprilOctober 2011, we obtain a similar situation of the southern slopes as compared with the southeastern and eastern versants - $43.8 \mathrm{~mm}$ less rainfall, higher temperatures by $0.37^{\circ} \mathrm{C}$ in the air and by $1.91^{\circ} \mathrm{C}$ at $10 \mathrm{~cm}$, by $2.22^{\circ} \mathrm{C}$ at $20 \mathrm{~cm}$, by $2.43^{\circ} \mathrm{C}$ at $30 \mathrm{~cm}$ soil depth compared to northern, north-western slopes. These issues, supplemented by those connected to slope, require special agrotechnical measures generated by the Transylvanian Plain topography.

Acknowledgments. This paper was published under the frame of European Social Fund, Human Resources Development Operational Programme 2007-2013, project no. POSDRU/159/1.5/S/132765 and was performed under the frame of the Partnership in priority domains - PNII, developed with the support of MEN-UEFISCDI, project no. PN-II-PT-PCCA-2013-4-0015: Expert System for Risk Monitoring in Agriculture and Adaptation of Conservative Agricultural Technologies to Climate Change.

\section{REFERENCES}

1. Baciu, N., (2006). Transylvania Plain, geo-ecological study. Cluj University Press, Cluj-Napoca.

2. Bunescu, V., G. Mihai, H. Bunescu, I. Man, (2005). Condiţiile ecologice şi solurile din Podişul Transilvaniei. Ed. AcademicPres Cluj-Napoca.

3. Dîrja, M., (2000). Fighting soil erosion. Risoprint Publishing House, Cluj-Napoca.

4. Hoble, A., M. Dîrja., E. Luca, L. Luca, T. Salagean, (2010). Estimations of soil-plant-climate relation in the conditions of the Transylvania fields. Bulletin USAMV Horticulture, 67:2, Ed. AcademicPress Cluj-Napoca.

5. Mac, I., (1987). Transylvania Plain, in the Romanian Geography. Vol. III, Romanian Carpathiansand the Transylvania Basin. The Academy of R. S. Romania Publishing House, Bucharest.

6. Montgomery, D. R., (2007). Soil Erosion and Agricultural Sustainability. Proceedings of National Academy of Sciences of United States of America, vol. 104, no.33.

7. Naum, T., M. Grigore, (1974). Geomorfologie. Ed. Didactică şi Pedagogică Bucureşti. 
8. Pop, G. (2001). Transylvania Basin. Cluj University Press, Cluj-Napoca.

9. Rusu, T., D. Weindorf, B. Haggard, P. I. Moraru, H. Cacovean, M. L. Şopterean, (2011). Soil moisture and temperature monitoring for sustainable land and water management in Transylvanian Plain, Romania. Geophysical Research Abstracts, Vol. 13.

10. Rusu, T., I. Bogdan, P. Moraru, A. Pop, C. Coste, (2013). Monitoring the thermic and hydric regime of soils in the
Transylvania Plain. Scientific Papers, vol. 39, Agronomy and Ecology, p. 97-106, Chişinău, Moldavian Republic.

11. Selby, M. J., (1993). Hill slope materials and processes. Oxford University Press, Edition 2, Oxford.

12. Weindorf, D.C., B. Haggard, T. Rusu, M. L. Sopterean, H. Cacovean, (2011). Interpretations of soil properties and soil climate in the Transylvanian Plain, Romania. Scientific Papers, Series A-LIV - Agronomy, USAMV Bucharest, p. 127-135. 